\title{
OM STRANDVANDRINGER OG ANNEN UNYTTIG EKSERSIS
}

\author{
Birthe Marie Løveid
}

Bildene, ordene og besøkerne i Kunstens hus...

Det handler om formidling. Det handler om formidling av kunst. Ikke på det merkantile plan. Når jeg nå snakker om virksomheter i Kunstens hus ser jeg på den fasen som allerede avklart gjennom galleriene og auksjonshusene. Refleksjoner omkring kunst som investeringsobjekt er en annen historie. Kunstformidlingen i museene er kulturformidling på høyt nivå, en viktig verdi- og holdningsskapende virksomhet.

Samlingene forvalter et kunskapsreservoar og en informasjonskilde vi ofte har vanskelig for a fatte rekkevidden av.

Bildene i Kunstens hus., når jeg tenker på dem, tenker jeg umiddelbart på de bildene som er kommet dit for à bli. For disse bildene personlig er det en kompleks affere:

Først og fremst er de sikret status. De er trolig sikret vedlikehold og bevaring $i$ en overskuelig fremtid. Men de kan risikere internering $i$ magasinene for alt fra noen til alle är, og den skjebnen er kanskje verre enn døden ogsä for et billede.....

Mange museer og samlinger driver gallerivirksomhet der de både låner verker av hverandre og trekker samtidskunsten inn på repertoaret. Denne formidlingsvirksomheten er et svært verdifullt supplement til museumsdriften, men også til den mer markedsorienterte gallerivirksomheten utenfor museene, og et laboratorium for utprøvninger av formidlingstanken.

Formidlingen i Kunstens hus er betydningsfull.

Men hvem er aktørene som befinner seg i Kunstens hus, hva driver de med, hvilke roller spiller de? Det er lett å bli så fylt til randen med assosiasjoner at man knapt vet $\mathrm{i}$ hvilken ende man skal begynne...

Personlig har jeg spilt i mange roller på den scenen jeg nà skal tegne opp for dere; som billedkunstner i allmennhet, som produsent av kunstverk, som besøker, som betrakter, som bruker, som formidler, som pedagog, som menneske....

\section{OM KUNSTMUSEER}

Kunstens hus. Det er en vakker formulering. Det ligge en høytid i ordene, men de formidler også holdninger som sier at i Kunstens hus oppfører man seg pent, der betrakter man, der reflekterer man som 
70 dannete mennesker, man samtaler. Museet som Kunstens hus er nesten som en kirke, en kirke for de innviede. Lyst, hvitt, rent, som sannheten selv.

Ja ikke alle museer da. I noen museer har misjonstanken grepet så om seg at den er blitt hengende som en giljotin over nakken på museumsfolkene. Der føler de seg tvungne og forpliktet til å kommunisere med barbarene. Hedningene, de som ikke har kunnskapen, verdinormen, og som sikkert ikke vil få den heller... Det blir skrekkelige utstillinger av slikt. Man får rent dårlig samvittighet når man kommer inn i slike museer.

Ikke fordi man har dårlig samvittighet, men fordi man av ren medfølelse tar inn over seg litt av den dårlige samvittigheten som ligger i veggene. En forfatterinne jeg kjenner kaller det for pedagogiske utstillinger. Det er når noen forsøker å være veldig pedagogiske og veldig psykologiske samtidig når de skal formidle kunst.

Ja, for det er kunsten som skal formidles? Er det ikke?

Det var jo ikke det til å begynne med. Den gangen billedkunsten, sammen med alt fra gråstein til beinkonstruksjoner av aper og eskimoer ble trukket inn under egne tak, handlet det om å registrere kunnskap. Putte viten i skap, vitenskap. På 1750-tallet ble estetikken en vitenskap, og kunsten fikk museer å være i og ble enda mere ekte enn den hadde vært før. Heldigvis er det grådig lenge siden... Eller... regner vi en generasjon for 20 år er det ca 12 generasjoner siden. Regner vi hver generasjon for 25 år er det bare 10 . Tenker vi på hvor lite katter forandrer seg, som lager en ny generasjon hvert år, er jeg glad jeg ikke er eskimo. Men hva med kunsten min?
Jeg venter litt med å reflektere over kunsten. Den har det sikkert bra i museene, den er jo opphøyet.... Jeg vil først titte litt på den besøkende, på betrakteren.

Hvem er det? I prinsippet kan jo det være hvem som helst. Alle vi som er her vet at slik er det ikke. Det synes jeg er trist. Hvorfor skal jeg fortelle litt senere.

\section{OM BESØKERE}

Først har vi betrakteren... selve betegnelsen er provoserende passiviserende dersom noen av oss skulle havne i den rubrikken av kategoriseringer. Men den er veldig anvendelig på alle andre. Da vet vi hvor vi har dem. Vi har full kontroll... vi har bukten og alle endene for å si det slik. Betrakteren er en vakker og jomfruelig gestalt, reseptiv, åpen og formbar, i alle fall $\mathrm{i}$ våre drømmer.

Men betrakteren kan også være en kikker. Grøss og gru. Drømmen blir til et mareritt. Enda verre dersom betrakteren er en kritiker. Det er en som er kunstkritiker og kikker samtidig. Og hvem er det som former hvem når man har slike $\mathrm{i}$ nærheten?

Men la oss nå trekke pusten dypt å tenke oss at besøkeren er et menneske, et menneske som går inn $\mathrm{i}$ Kunstens hus. Hva gjør det der? Det går på jakt. Det jakter på opplevelse. Kunstopplevelse. Det jakter på informasjon og impulser, det jakter på gjenkjennelse og bekreftelse, det jakter på overraskelse, det jakter på ideer. Denne jegeren kan være hvem som helst av oss, men den som forvalter jaktmarkene må ikke glemme at det er jegere og ikke byttedyr som kommer inn gjennom dørene. Det er noen som har sult i seg som kommer. 
De innviede, kulturarbeiderne, kunstnerne, de dannede menneskene, leter etter overraskelser og utfordringer når de går på jakt til museene. Lekfolket, de ufaglærte, leter etter gjenkjennelser først og fremst fordi de ikke kjenner skogen. Det er helt riktig og helt viktig å gjøre det når du som jeger kommer ny til et jaktfelt. Men når de da møter tamelg tjoret til påler og får utdelt luftgevær ved inngangen føler de seg helt naturlig undervurdert. De kjenner helt sikkert samme ubehag eller lede som vi ville gjort i tilsvarende situasjon.

Det er så lett å undervurdere publikum, som kan være deg eller meg, som kan være hvem som helst. Det er dette som gjør meg trist: Det er de som ikke føler seg undervurdert som kommer til Kunstens hus. I parentes bemerket er følelser en svært alvorlig faktor som må taes ytterst seriøst i formidlingen.

Heldigvis har noen fortalt meg at de som holder på med galluper, særlig her i Sverige, sier at det blir fler og fler som går i kunstmuseer. Jeg vil likevel påstå at vi her oppe i Norden undervurderer publikum og derigjennom konserverer et klasseskille når det gjelder vår omgang med kunst. Om dette ironisk nok stammer fra sosialdemokratiets svermeriske og inkluderende likhetsprinsipp eller Jantelovens ekskluderende gjerrighet, vet jeg ikke. Men det er utrolig mange som blygt senker blikket og sier at de ikke forstår seg på kunst... Da er det heller ikke så rart at de som skal formidle kunsten som oftest har tatt seg dette som et utgangspunkt.

\section{OM KUNSTEN SELV}

Jeg har lyst til å dvele litt ved kunsten selv. Den kunsten som museene skal forvalte og formidle. Hva gjør vi med det faktum at billedkunsten er $\mathrm{i}$ ferd med å erobre nye uttrykksformer? At den er i ferd med å befeste status, i det billedkunstens ingenmannsland som har oppstått når mesteparten av vår mediaverden, uhemmet har tatt bildet i bruk til hva det enn måtte være.

Og samtidig vakler billedkunstens gamle, men kanskje illusjonistiske skanser.

Mens musikken kryper inn i evighetskappen og mangfoldiggjør seg i form av grammofonplater, bånd og CDer, føler store deler av billedkunsten at evighetskappen er blitt for trang, og mangfoldiggjørelsen uinteressant, og springer naken ut på markene for å eksponere sitt budskap i nuet og forsvinne med nuet.

I dag er vi i ferd med, for alvor, å bli bevisste at kunsten ikke er evig.

Den har en sårbar kropp som kan stjeles og knuses og vandaliseres.

I dag diskuterer vi et kunstverks rett til å dø. For eksempel i utsmykkingssammenheng, der den integrerte kunsten ofte ikke har annet valg enn å følge sin arkitektoniske livsledsager på fyllinga når bygget skal rives.

Billedkunsten har en gammel, hevdvunnen rett til ikke å være salgbar. En rett den har tilegnet seg i bytte mot å være bærer av åndelige verdier.

Mange av vår samtids viktigste billedkunstneriske ikoner er simpelthen uselgelige både i form og uttrykk. En av museenes viktigste oppgaver er å gjøre denne kunsten tilgjengelig for oss. Hvordan tenker man seg å forvalte denne oppgaven $\mathrm{i}$ fremtiden? Gjennom hvilke kanaler finner museene verkene sine? Hvem eller hva er det som stiller premissene og for hvem?

Erfaringer fra arbeid med blinde besøke- 
72 re har gitt meg mye å tenke på i disse sammenhengene.

Jeg ble invitert til å delta på utstillingen Motestedet arrangert av Henie-Onstad Kunstsenter ved Oslo, tilrettelagt for blinde og svaksynte.

Ideologien bak denne utstillingen var ikke å lage kunst for blinde, men gjennom arrangementer i utstillingslokalet legge forholdene til rette for at utstillingen ble tilgjengelig også for blinde.

"Integrering», "tilpassing», "dogmer» og «fordommer» var begreper som stadig dukket opp under arbeidet med prosjektet. Hva innebar f.eks. «integrering» $\mathrm{i}$ denne sammenhengen? Det innebar at kunstverket ble tilrettelagt for at blinde og svaksynte også skulle kunne bruke kunsten, oppleve den og orientere seg i den uten bruk av hjelpere som tolket og fortolket. Det er det viktige poenget. Først da er man fri og samtidig en av klanen, med fiskekort og jaktrettigheter.

Langt på vei oppnådde utstillingen Møtestedet denne målsettingen. En av de blinde som kom for å se den beskrev sin opplevelse i tre ord: «Frigjort, gjenkjent og verdsatt."

\section{OM TILGJENGELIGHET}

Kjenner dere at dere begynner å nærme dere stranden nå? Apropos strandvandringen i tittelen på disse ytringene....

Så vakre blomster til vernissasjen er det sjeldent at vi får. Men på storsamfunnets vegne, i parentes et utrykk de norske samene så beskrivende har satt på alle andre nordmenn, er det flaut å si at kritikerne meldte pass fordi de ikke stolte på at integreringen stoppet ved den praktiske tilpassingen av tilgjengelighet. Kunsten kunne jo også være «tilpasset» og da er det tvilsomt om den er ekte kunst lenger? At kunstens evne til å tilpasse seg en kommunikasjonssituasjon kanskje er dens mest vitale egenskap sett i lys av dens oppgave som språkbærer, det som gjør den til kunst simpelthen. Dette glemmer man fort når tilpassingen ikke er rettet med eller mot den kjente og kjære kunstscenen. Vår kunstscene. Men nå var det ikke kunsten denne gangen som var tilpasset, det var utstillingen, $\mathrm{i}$ alle fall for de fleste kunstverkenes vedkommende.

Eksemplet berører et generelt problem når det gjelder kunsten. Den er ustabil og relativt flyktig som kvalitativ verdibærer. Både hvem som ser den, hvor den vises og

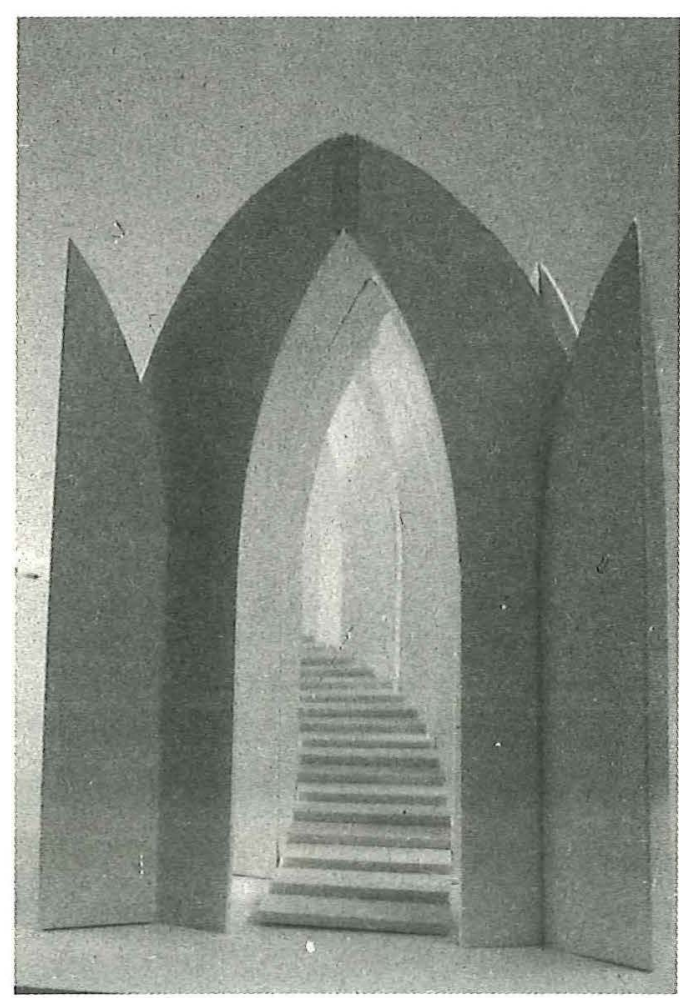


Det fantes ikke tilgjengelig noen gode bilder fra «Motestedet». Forfatteren vil istedet illustrere artikkelen med bilder (se under) fra et prosjekt hun nå er opptatt med, "Landet innenfor" - en musikk- og billedkomposisjon for barn og barnefragmenter. Begrunnelsen for prosjektet ligger $i$ et syn på mennesket og kunsten som Birthe Marie Loveid formulerer slik:

Barn er en spennende og sammensatt gruppe. Tenk om begrepet BARN bestair av de hele, virkelige barna, de menneskene som har levet kort. Og delbarna, barne-fragmentene som finnes $i$ alle mennesker som er eldre enn barn. De som har levet lengre.

Mesteparten av barnas liv går med til å bli kjent med alle språkene. Da tenker jeg ikke på de verbale språkene som norsk og engelsk, men pa de språkene som gjor at vi kan kommunisere med hverandre, kroppsspråket for eksempel. Barna trenger à lare seg alle disse språkene for à bli funksjonelle voksne. Hver språkgruppe representerer ogsai en kunstart: Musikk, teater, ballett, litteratur, arkitektur, billedkunst. Alt dette finnes $i$ barnas lek og barnas tanker som kommunikasjonsberere.

Kunsten er spräkformer vi trenger til erkjennelse. Erkjennelser og utvikling horer sammen. Vi utvikler oss hele livet, men relativt sett utvikler vi oss mest og raskest når vi er barn. Derfor er kunstspråkene så synlige i alle barns lek. Og derfor er kunsten sà viktig for barna.

$A$ ta utgangspunkt $i$ en verden der alt er mulig, er av vital betydning for alle forskere, oppfinnere, kunstnere, ja alle mennesker som onsker å tilfore oss noe mer, noe nytt, noe som ikke var her for. Hele vår kulturelle og historiske utvikling springer ut fra dette lille, denne egenskapen som vi kaller barnas naive sjarm.

Eller: Kreativitet.




74 hvem som kjøper den influerer på verdien. Når blinde kommer for å se på den, det betyr selvfølgelig noe så prosaisk som at de tar på den, kan vi forstå at en kritiker tviler på at det er kunst det dreier seg om, selv om det blir vist $\mathrm{i}$ et vaskeekte Kunstens hus.

Men så sier konservatorene at billedkunst som blir tatt på ikke kan konserveres på normal måte og taper sin verdi som duggen forsvinner for solen, så museene kan heller ikke forholde seg til billedkunst som også kunne ha noe å formidle gjennom det taktile sanseapparatet. Til mennesker som av en eller annen grunn ikke kan se. Men de kan føle... denne alvorlige og viktige faktoren $\mathrm{i}$ all formidling....

Det ligger farlige diskrimineringsaspekter og gjærer under holdningene til denne forsteningskulturen, unnskyld bevaringskulturen, som vil putte alt i bås. Hver gullkalv skal ha sin bås og sine røktere og vi går føydalherskeren en høy gang når det gjelder å produsere attributter og ritualer for å skille de som er innenfor og de som er utenfor.

I dette perspektivet fremstår et handikap eller en annerledeshet som en befriende ressurs. Et redskap og en indikator for à finne fram til nye refleksjoner så vi ikke går oss bort i sekterisme. Et klareskinn, slikt som man puttet i kaffekjelene i gamledager for at kaffen skulle bli klarere. Vi trenger det for at informasjonen vi sprer om oss i kunstformidlingens navn skal bli introduksjoner og ikke bortforklaringer. Når utstillingen Møtestedet inviterer til å ta på kunsten, er det like mye en protesthandling mot et ekskluderende aspekt ved kunstformidlingen, som en invitasjon til nye brukergrupper. $\mathrm{Og}$ de synshemmede kan bli katalysatorer, - dør- åpnere til nye rom det kan vise seg viktig for oss at vi kom inn i.

\section{KUNSTEN SOM FLASKEPOST}

«Det eneste kunsten kan handle om er møtet mellom et menneske og verden", sa Jens Bjørneboe, nå avdød norsk forfatter. Da sier han at kunsten angår alle. At vi gjennom kunsten bearbeider vårt forhold til det som omgir oss. At kunsten er inkluderende og ikke ekskluderende.

For kunst er mye mer enn å lage vakre ting med vakre farger og skjønne former, kunst er å vite og våge og ville. Kunst er å beskrive forståelsen og kunnskapen om alt som er virkelig viktig for menneskene. $\mathrm{Og}$ det kan være stort eller lite, lokalt eller globalt. Kunst handler om bevissthet.

Men som det vakre landskapet som bare ligger der ute i ødemarken, det blir ikke vakkert før du eller jeg kommer dit og blir bevisste at det ligger der og er vakkert. Kunsten blir ikke kunst før noen finner den og ser på den eller føler på den at den er kunst.

Kunstnerne, vi sitter og sender ut våre erkjennelsesbilder på havet som flaskepost og håper at Den Rette skal finne dem og gjøre dem til kunst. De fleste flaskene forsvinner i bølgene. Bare noen ganske få, det synes oss ofte tilfeldig valgte, finner seg en strand til å bli skyllet opp på. Den stranden kan være et museum, et Kunstens hus der bilder blir kunst. Men vi kan aldri være sikre på om noen finner brevet vårt selv om flasken vår ligger der i sanden og lyser som et varmt løfte.

På strendene i Kunstens hus spiller tiden en viktig rolle. Alle flaskene har årstall som i en vinkjeller. Metaforen er ikke så dum om jeg får si det selv, vi er mer opp- 
tatte av å samle på flaskene enn å smake på innholdet.

De flaskene som ikke har årstall får nesten mer årstall enn alle de andre, fordi det at de ikke har årstall får en tendens til å bli den viktigste egenskapen ved dem.

I Kunstens hus er Tiden lineær. Der relaterer vi oss til historien og til samTiden, og ordner flaskene våre i pene rekker.

Tiden er en kraft det står respekt av. Den ligger som et kjernekraftverk bak trendene i Kunsten og pumper ut energi. Som kunstnere opplever vi at den har en uhyre makt. Den har makt til å kanonisere oss (..årets Kunstner, deseniets Kunstner, århundredets Kunstner..), den kan utslette oss (..nå har vi ikke sett noe fra henne på lenge, han er helt ute, hun har ikke fornyet seg, kunsten hans er helt avlegs, hun er død som kunstner..), den kan forgjøre oss til vi ikke kjenner oss selv. (..han er blitt en kopi, hun er helt trendy, nei gud jeg trodde ikke det var deg, jeg kjente ikke igjen streken din, å unnskyld hadde vi truffet hverandre før på utstillingen din sa du?..) Tiden er noe vi kunstnere har respekt for.

Dere vil bli forundret om dere visste hvor mye tidsangst som finnes der kunsten er og der kunsten blir til. I vår verden $i$ vår kulturkrets $i$ vår Tid.

I og omkring kunsten finnes et maktspill der tidsangsten er blitt et billig og effektivt våpen for å skape ro og orden $\mathrm{i}$ rekkene. Jeg tar sikkert ikke munnen for full om jeg sier at de fleste kunstnere med ambisjoner, før eller siden og i større eller mindre grad, iblant våkner opp og føler klamheten ved å befinne seg $\mathrm{i}$ en slik ordnet rekke.

Tiden kan erobres. Tiden kan bli en venn. Tiden kan bli en beskyttelseskappe, en befrier og en forløser. Men da må vi se at Tiden er noe som omgir oss, og ikke noe som løper fra oss.

Kunsten krever bevissthet, så den kan få være modig, vakker og fri. Men overalt finnes valgplakater og reklame som vil tåke til bevisstheten så vi som kunstnere ikke ser skjønnheten i motet og friheten. Det er så lett å forråde det fineste i Kunsten. Tenk bare på hvor lett det er å bli foraktelig og uinteressert i kunst som av en eller annen grunn ikke passer inn i flaskesamlingen?

Kjare museer, dere er strender, ikke vinkjellere. Apne dere og la oss få søke i sanden - om vi er halte eller blinde. Ta vare pà skattene våre, ta vare på kroppene deres så lenge de lever, men la oss fä innholdet.

Tenk à få gå på en solvarm strand a jakte på flaskepost. Vi fanger flasken, finner brevet og vi åpner det. Alt stemmer, det står der, det vi ikke visste, men som vi visste likevel. Hinsides Tiden finnes en felles erkjennelse. Det er lykke.

\section{SUMMARY}

\section{About shore-walks and other idle amusements}

The author, who is a sculptor and the leader of the Academy of Fine Arts in Bergen, Norway, looks at the art museum with mixed feelings. The works of art which have attained the status of museum objects have been salvaged from the relentless flow of time. But, alas, many of them are doomed to the store-room or cellar.

Even to be accorded a public space in the exhibition hall is a dubious success. The art museum is a relative of the church, it demands deference from its users; and like the church it has a missionizing inclination, which all too often has a devastating 
76 influence upon the exhibitions and gives the visitor a bad conscience. The museums too frequently underestimate the visitors' capacity to make their own judgements and choices. In fact most visitors are starved of experience, they are hunters after visual adventures. The experienced hunter wants surprises and challenges, the ignorant look for recognition and confirmation.

The ongoing changes in art also pose new problems in relation to the museum, such as the exploitation of pictures in the mass media, the source of most people's mediated visual experience of art. A particular project, The Meeting-place, presented at Henie-Onstad Art Centre in Oslo, where blind people were invited to meet contemporary art and where, without the interference of mediators, they could feel their way through the exhibited works, which were not adapted or specially arranged for the blind, afforded a special opportunity to reflect on serious communication problems in museums. There are dangerous discriminating aspects lurking behind the attitudes of the museum culture, which wants to conserve and preserve everything in safe cases. For every golden calf its case and its curator and rules and rituals are produced to separate the few to be admitted from the multitude to be left outside.

The artist puts a message in a bottle and throws it into the sea expecting the Right One to find it and respond. Museums are shores where the bottles land. There the concept of Time rules, the bottles are dated and arranged according to period and year, like bottles in a wine cellar according to their vintage. But we must realize that Time does not run away from us, it surrounds us - especially in museums. Let museums be shores where we are free to roam, hunting for half-hidden bottles with exciting messages!

* Artikkelen bygger på foredrag under Museidagar 7-8. oktober 1994 ved Institutionen för museologi, Umeå Universitet.
Birthe Marie Loveid er billedkunstner og rektor for Vestlandets Kunstakademi i Bergen Adr. Vestlandets Kunstakademi, C. Sundtsgt. 53 , N-5004 Bergen, Fax +47-55 902570 